J. Asiat. Soc. Bangladesh, Sci. 40(2): 271-281, December 2014

\title{
PEDOGENESIS AND CHARACTERIZATION OF SOME SOILS FROM THE CHALAN BEEL OF BANGLADESH
}

\author{
A.B.M.S. ISLAM ${ }^{1}$, Z.H. KHAN ${ }^{2 *}$ AND A.R. MAZUMDER ${ }^{2}$ \\ 'Department of Soil Science, Patuakhali Science and Technology \\ University, Patuakhali, Bangladesh. \\ ${ }^{2}$ Department of Soil, Water and Environment, University of Dhaka, Dhaka-1000, Bangladesh.
}

\begin{abstract}
Twenty two soil samples from four pedons representing some established soil series namely Jaonia, Halti, Taras and Digli from the Chalan beel area of Bangladesh were studied in the field as well as in the laboratory for their pedogenesis and characterization. All the soils are heavy textured with clay contents ranging from 47 to 60 percent. The soils are moderately acidic to neutral in reaction with high base saturation. The soils have developed redoximorphic features including redox concentration and redox depletion due to periodic flooding more than 4 months in the monsoon season. Development of cambic horizon in these soils is the most notable morphogenetic feature. Gleization and weak hydromorphism are the dominant pedogenic processes. At the subgroup level the soils were classified as Typic Endoaquepts and Aeric Endoaquepts. Finally the soils are characterized at the family level of soil taxonomy.
\end{abstract}

Key words: Chalan beel, Soil morphology, Pedogenesis, Characterization

\section{Introduction}

Chalan beel, the largest beel in Bangladesh, is a low lying wetland area between the Barind tract and the Ganges river floodplains. It is located between $24^{\circ} 05^{\prime}$ to $24^{\circ} 35^{\prime} \mathrm{N}$ latitude and $89^{\circ}$ to $89^{\circ} 35^{\circ} \mathrm{E}$ longitude. The Chalan beel area belongs to the physiographic unit lower Atrai basin (FAO-UNDP 1988). The beel extends over the adjacent districts of Sirajgonj, Natore and Naogaon. It comprises a series of depressions inter-connected by various channels to form more or less one continuous cover of water in the rainy season. A survey carried out in 1909 by the Public Works Department showed that the previous area of the Chalan beel was about $1,08,800$ ha which had been reduced to 36,800 ha due to fast silting up of the beels (Islam 2003). Bangladesh has a wide range of soils developed on parent materials ranging from recent alluvial deposits to sedimentary rocks of tertiary formation (Saheed and Hussain 1992). "Atrai river alluvium" is the parent material of Chalan beel soils which covers an area of around 98,000 ha of the total area of Bangladesh (Hussain 1992). The soils of Chalan beel are seasonally flooded and the duration of the flooding is 4-5 months on an average. The drainage condition of that area is very poor. In the seasonally flooded soils of Chalan beel, mottles are the important redoximorphic features. They are reliable indicators of aquic moisture regime (Saheed and Hussain 1992) in the body of the soils, they are formed by both epiaquic and

Corresponding author: khanzh_du@yahoo.com 
endoaquic mechanisms. Studies on the mottles in the Chalan beel soils of Bangladesh are very few. Most of them are considered to be constituted of goethite and lepidochrocite minerals. Flood coatings are also common and extensive in these seasonally flooded soils of Bangladesh. This pedomorphic feature has, however, been very inadequately studied, even though it is highly important. Chalan beel is silting up rapidly. Almost the whole of the beel has now been scatteredly settled and is under cultivation during the dry season and rice is the main crop of that area. These noncalcareous floodplain soils are very important from agricultural point of view. Characterization of soils of the Chalan beel at the family category of soil taxonomy will be useful to the soil scientists, agronomists, farm research scientists and the agricultural extension workers involved in agricultural development as well as the agro-technology transfer programs. Now-a-days it is an established fact that pedogenic information about soils is a prerequisite for sound and sustainable land management. Therefore this research work was carried out to characterize some soils of the Chalan beel area at the family level of Soil Taxonomy.

\section{Materials and Methods}

Four soil profiles representing four established soil series, viz., Jaonia, Halti, Taras, and Digli were opened up and studied in the field for their morphogenetic properties. The locations of the four soil profiles are marked in Fig. 1. Morphogenetic features of the studied pedons and their horizonation in the soil profiles are shown in Plate 1. Information about the location, land types, land use, inundation period and parent material are presented in Table 1. Reconnaissance Soil Survey Report was used to perform this survey. Soil pedons were described following the FAO guidelines (FAO 1977). Morphological characteristics were described according to the system of Soil Survey Staff (1993). A total of 22 soil samples was collected on horizon basis for laboratory analyses. Particle size analysis of soil was carried out by combination of sieving and hydrometer methods (Day 1965). Soil pH was determined at a soil : water and soil : $\mathrm{KCl}$ ratio of $1: 2.5$. Organic carbon in soil was determined by Walkley and Black wet oxidation method (Jackson 1967), total nitrogen by Kjeldahl's method (Jackson 1967), cation exchange capacity (CEC) by $1 \underline{\mathrm{N}} \mathrm{NH}_{4} \mathrm{OAc}$ method (Jackson 1967) and exchangeable cations $\left(\mathrm{Ca}^{2+}, \mathrm{Mg}^{2+}, \mathrm{Na}^{+}\right.$and $\left.\mathrm{K}^{+}\right)$were determined from $1 \underline{\mathrm{N}} \mathrm{NH}_{4} \mathrm{OAc}$ (pH 7) extract as described by Jackson (1967). Exchangeable $\mathrm{Ca}^{2+}$ and $\mathrm{Mg}^{2+}$ were determined by atomic absorption spectrophotometer (AAS), and $\mathrm{Na}^{+}$and $\mathrm{K}^{+}$by flame photometer. Clay fraction $(<2 \mu \mathrm{m})$ of the surface soil was separated by repeated sedimentation-siphoning method (Jackson 1975). Semi-quantitative analysys of clay minerals of clay fraction was estimated on the basis of the relative peak intensities in the X-ray diffraction (XRD) patterns as described by Islam and Lotse (1986). 


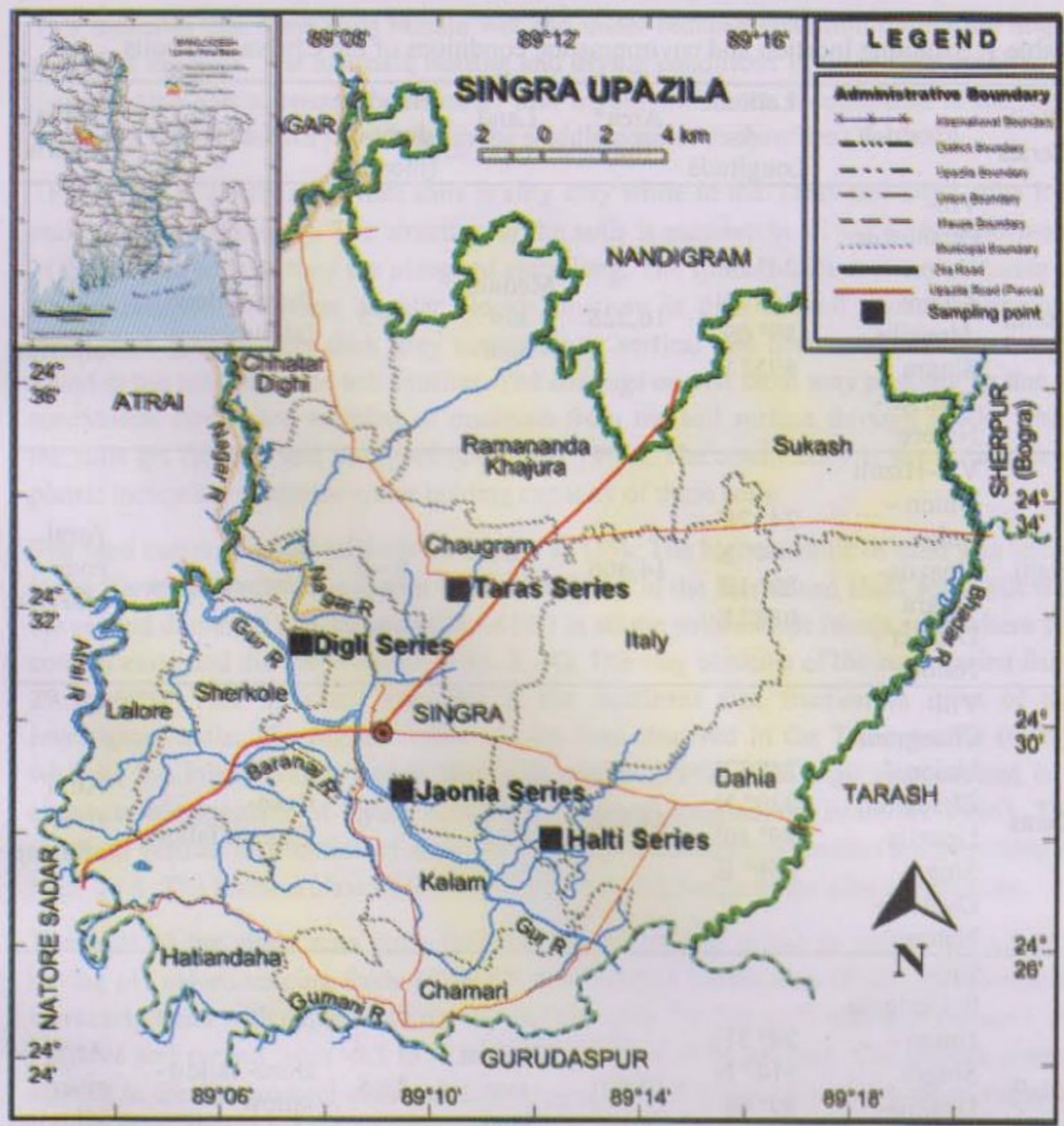

Fig 1. Map showing the location of soil sampling sites in the Chalan beel area of Bangladesh.

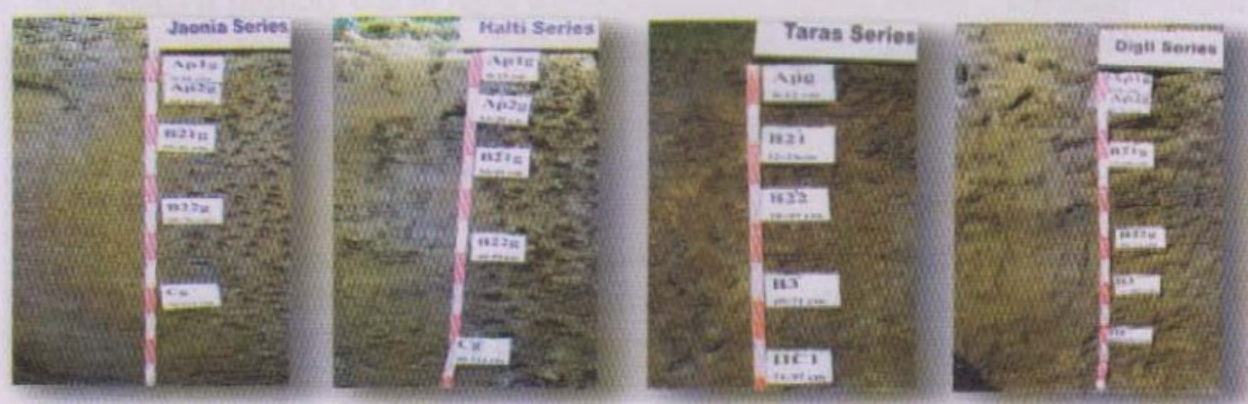

Plate 1. Pictures showing the profile features and horizonation of Jaonia, Halti, Taras and Digli soils (from left to right). 
Table 1. Sampling location and environmental conditions of the Chalan beel soils.

\begin{tabular}{|c|c|c|c|c|c|c|c|}
\hline $\begin{array}{c}\text { Soil } \\
\text { Series }\end{array}$ & Location & $\begin{array}{l}\text { Latitude } \\
\& \\
\text { Longitude }\end{array}$ & $\begin{array}{l}\text { Area* } \\
\text { (ha) }\end{array}$ & $\begin{array}{l}\text { Land } \\
\text { type }\end{array}$ & $\begin{array}{l}\text { Flooding } \\
\text { duration } \\
\text { (months) }\end{array}$ & Land use & $\begin{array}{l}\text { Parent } \\
\text { material }\end{array}$ \\
\hline Jaonia & $\begin{array}{l}\text { Vill- } \\
\text { Parshawile } \\
\text { Union- } \\
\text { Kalam } \\
\text { Upazila- } \\
\text { Singra } \\
\text { District - } \\
\text { Natore }\end{array}$ & $\begin{array}{l}24^{\circ} 29^{\prime} \\
049^{\prime \prime} \mathrm{N} \\
89^{\circ} 09^{\prime} \\
495^{\prime \prime} \mathrm{E}\end{array}$ & 16,228 & $\begin{array}{l}\text { Medium } \\
\text { low } \\
\text { land }\end{array}$ & $4-5$ & $\begin{array}{l}\text { Boro-fallow- } \\
\text { fallow }\end{array}$ & $\begin{array}{l}\text { Atrai } \\
\text { river } \\
\text { alluvium }\end{array}$ \\
\hline Halti & $\begin{array}{l}\text { Vill-Hizoli } \\
\text { Union - } \\
\text { Italy } \\
\text { Upazila- } \\
\text { Singra } \\
\text { District - } \\
\text { Natore }\end{array}$ & $\begin{array}{l}24^{\circ} 28^{\prime} \\
464^{\prime \prime} \mathrm{N} \\
89^{\circ} 12^{\prime} \\
088^{\prime \prime} \mathrm{E}\end{array}$ & 14,406 & $\begin{array}{l}\text { Low } \\
\text { land }\end{array}$ & $5 \cdot 6$ & $\begin{array}{l}\text { Boro- } \\
\text { T.aman/fallow }\end{array}$ & $\begin{array}{l}\text { Atrai } \\
\text { river } \\
\text { alluviun }\end{array}$ \\
\hline Taras & $\begin{array}{l}\text { Vill- } \\
\text { Chaugram } \\
\text { Union - } \\
\text { Chaugram } \\
\text { Upazila- } \\
\text { Singra } \\
\text { District - } \\
\text { Natore } \\
\end{array}$ & $\begin{array}{l}24^{\circ} 32^{\prime} \\
039^{\prime \prime} \mathrm{N} \\
89^{\circ} 10^{\prime} \\
659^{\prime \prime} \mathrm{E}\end{array}$ & 44,678 & $\begin{array}{l}\text { Low } \\
\text { land }\end{array}$ & $5-6$ & $\begin{array}{l}\text { Boro- } \\
\text { T.aman/fallow }\end{array}$ & $\begin{array}{l}\text { Atrai } \\
\text { river } \\
\text { alluvium }\end{array}$ \\
\hline Digli & $\begin{array}{l}\text { Vill- } \\
\text { Rakhalgasa } \\
\text { Union- } \\
\text { Singra } \\
\text { Upazila- } \\
\text { Singra } \\
\text { District - } \\
\text { Natore }\end{array}$ & $\begin{array}{l}24^{\circ} 31^{\prime} \\
514^{\prime \prime} \mathrm{N} \\
89^{\circ} 08^{\prime} \\
730^{\prime \prime} \mathrm{E}\end{array}$ & 17,821 & $\begin{array}{l}\text { Medium } \\
\text { low } \\
\text { land }\end{array}$ & $4-5$ & $\begin{array}{l}\text { Boro- fallow- } \\
\text { fallow }\end{array}$ & $\begin{array}{l}\text { Atrai } \\
\text { river } \\
\text { alluvium }\end{array}$ \\
\hline
\end{tabular}

* Hussain et al. (2003)

\section{Results and Discussion}

The matrix colour of the soils is a combination of grey and dark grey and grayish olive. Under moist condition, the colour of the surface horizon was found to be very dark gray (5Y3/1) in Jaonia, Halti and Taras pedons, while it was dark grey (5Y4/1) in Digli pedon. The above colours in the soils developed due to their seasonal submergence. All the soils have uniform grey matrix colour throughout the profile with gleyed layer or g-horizon. 
This indicates that these soils remain wet and under reduced condition during the major period of the year. The alternate wetting and drying conditions in these soils resulted in the reduction and subsequent release of iron oxides which are accumulated in the form yellowish brown mottles prominant in the middle zone of the profiles (Table 2).

The texture of Jaonia and Halti soils is silty clay while in the Taras and Digli soils it is mainly clayey (Table 2). The structure of the soils is massive in all the surface horizons of the studied soils as they are ploughed since long. The studied soils showed moderate to strong, medium to course angular blocky structure in their subsoil zone. Continuous, thick, dark grey to very dark grey cutans along vertical and horizontal ped faces were found in the middle of the soil profiles. The coatings on ped faces may possibly be due to mechanical downward washing of materials from the soil surface through cracks when the soils get flooded and ploughed (Brammer 1996). The consistency is firm, sticky and plastic indicating moderate water holding capacity of these soils.

The sand contents in the soils varied from 1 to $18 \%$. The highest value of sand was found in the Taras soils while the lowest value was found in the Jaonia and Halti soils. Silt was the second dominant size fraction $(28-61 \%)$ in all the soils except Jaonia soils where silt content exceeded the clay content (Figs. 2 - 4). The clay contents of the soils varied from 29 to $69 \%$. This indicates that clay is the dominant size fraction in most of the investigated soils. The highest value of clay was observed in the Taras profile $(69 \%)$, whereas the lowest value was in the Digli profile $(29 \%)$. This high clay content is a characteristic property of lower Atrai basin soils of Bangladesh (Brammer 1996). The trends of vertical distribution of sand, silt and clay in various soil profiles are presented in Figs. 2 - 4 . The textural class of the investigated soils belongs to the silty clay to clay.

The soils of the study area were found to be moderately acidic to neutral in reaction having $\mathrm{pH}$ values ranging from 6.2 to 7.1. The vertical distribution of $\mathrm{pH}_{\text {water }}$ showed an increasing trend with depth in all the soil profiles (Fig. 5). The $\Delta \mathrm{pH}$ values of the soils are negative and ranged from -0.5 to -1.0 with a mean of $-0.74 \mathrm{pH}$ unit. The organic matter content in the Chalan beel soils was low ranging from 0.38 to 2.40 with a mean value of 1.04 percent (Fig. 6). Low organic matter content is a common problem in Bangladesh soils which is possibly due to rapid decomposition of organic matter. The total nitrogen content in the soils ranged from 0.04 to 0.17 percent with a mean of 0.08 percent and showed a decreasing tendency with depth in all the pedons and the decrease is more or less gradual which is a sign of their development (Fig. 7). The $\mathrm{C} / \mathrm{N}$ ratio in the soils ranged from 4 to 12 with a mean ratio of 8 . The trends of vertical distribution of $\mathrm{C} / \mathrm{N}$ ratio in the various soil profiles are presented in Fig. 8. 
Table 2. Coded* morphological properties of the studied soils from the Chalan beel of Bangladesh.

\begin{tabular}{|c|c|c|c|c|c|c|c|c|}
\hline \multirow[b]{2}{*}{$\begin{array}{l}\text { Soil } \\
\text { Series }\end{array}$} & \multirow[b]{2}{*}{ Horizon } & \multirow[b]{2}{*}{$\begin{array}{l}\text { Depth } \\
(\mathrm{cm})\end{array}$} & \multicolumn{2}{|c|}{ Munsell Colour } & \multirow[b]{2}{*}{ Texture } & \multirow[b]{2}{*}{ Structure } & \multirow[b]{2}{*}{ Consistence } & \multirow[b]{2}{*}{ Boundary } \\
\hline & & & $\begin{array}{l}\text { Matrix } \\
\text { (moist) }\end{array}$ & Mottles & & & & \\
\hline \multirow{5}{*}{ Jaonia } & Aplg & $0-10$ & $5 Y 3 / 1 v d g$ & fldyb & Silty clay & Massive & ws, wp,mvfi & as \\
\hline & Ap2g & $10-15$ & $5 \mathrm{Y} 4 / 2 \mathrm{go}$ & fldyb & Silty clay & Massive & ws, wp, mvfi & as \\
\hline & B21g & $15-41$ & $5 Y 5 / 2 \mathrm{go}$ & m2pyr & Silty clay & $2 m-$ fabk & ws, wp,mfi & cs \\
\hline & $\mathrm{B} 22 \mathrm{~g}$ & $41-76$ & $5 Y 5 / 1 \mathrm{dg}$ & m2ddyb & Silty clay & $3 c$-mabk & ws, wp,mfi & cs \\
\hline & $\mathrm{Cg}$ & $\begin{array}{l}76- \\
114+\end{array}$ & $5 \mathrm{Y} 4 / 2 \mathrm{go}$ & $\mathrm{f} 2 \mathrm{dyb}$ & Silty clay & - & ws, wp & - \\
\hline \multirow{5}{*}{ Halti } & Aplg & $0-13$ & $5 Y 3 / 1 v d g$ & $\mathrm{~m} 2 \mathrm{pyb}$ & Silty clay & Massive & ws, wp,mfi & as \\
\hline & Ap2g & $13-20$ & $5 \mathrm{Y} 4 / 2 \mathrm{dg}$ & mldrb & Silty clay & Massive & ws, wp, mvfi & as \\
\hline & $\mathrm{B} 21 \mathrm{~g}$ & $20-48$ & $5 \mathrm{Y} 5 / 2 \mathrm{go}$ & $\mathrm{m} 2 \mathrm{pyr}$ & Clay & $2 \mathrm{~m}$-fabk & ws, wp,mfi & cs \\
\hline & B22g & $48-90$ & $5 Y 5 / 1 \mathrm{dg}$ & m2ddyb & Silty clay & $3 c$-mabk & ws, wp,mfi & cs \\
\hline & $\mathrm{Cg}$ & $\begin{array}{l}90- \\
114+\end{array}$ & $5 \mathrm{Y} 4 / 2 \mathrm{go}$ & f2ddyb & Silty clay & - & ws, wp, & - \\
\hline \multirow{6}{*}{ Taras } & Apg & $0-12$ & $5 Y 3 / 1 v d g$ & $\mathrm{mlpb}$ & Clay & Massive & ws, wp,mfi & as \\
\hline & B21g & $12-28$ & $5 \mathrm{Y} 4 / 1 \mathrm{~g}$ & $\mathrm{mlpb}$ & Clay & Massive & ws, wp,mfi & es \\
\hline & $\mathrm{B} 22$ & $28-49$ & $5 Y 5 / 1 \mathrm{~g}$ & mldyb & Clay & 2 cabk & ws, wp,mfi & cs \\
\hline & B3 & $49-71$ & $5 \mathrm{Y} 5 / \mathrm{lg}$ & mldyb & Clay & lcabk & ws, wp,mfr & cs \\
\hline & IICl & $71-97$ & $5 Y 5 / 1 \mathrm{~g}$ & mldyb & Silty clay & $2 \mathrm{cabk}$ & ws, wp,mfr & cs \\
\hline & IIC2 & $\begin{array}{l}97- \\
122+\end{array}$ & $5 Y 5 / 1 \mathrm{~g}$ & mldyb & Clay & $3 c-f a b k$ & ws, wp,mfr & - \\
\hline \multirow{6}{*}{ Digli } & Aplg & $0-8$ & $5 \mathrm{Y} 4 / 1 \mathrm{dg}$ & mlpyb & Clay & Massive & ws, wp,mfi & as \\
\hline & Ap2g & $8-13$ & $5 \mathrm{Y} 4 / 2 \mathrm{~g}$ & $\mathrm{~m} 2 \mathrm{pb}$ & Clay & Massive & ws, wp, mvfi & as \\
\hline & B21g & $13-48$ & $5 Y 5 / 1 g$ & m2pyb & Clay & $3 \mathrm{vcpr} / \mathrm{abk}$ & ws, wp, mvfi & cs \\
\hline & B22g & $48-74$ & $5 Y 5 / 1 g$ & mlpyb & Clay & $2 \mathrm{cpr}$ & ws, wp,mfi & cs \\
\hline & B3 & $\begin{array}{l}74- \\
102\end{array}$ & $5 Y 3 / 1 \mathrm{vdg}$ & clddyb & Silty clay & lcabk & wss,wps,mfi & cs \\
\hline & IIC & $\begin{array}{l}102- \\
140+\end{array}$ & $5 Y 5 / 1 g$ & - & $\begin{array}{c}\text { Silty clay } \\
\text { loam }\end{array}$ & - & wss, wp & - \\
\hline
\end{tabular}

* Abbreviations are according to Soil Survey Manual (Soil Survey Staff 1993). Colour: $g=$ grey, dg $=$ dark grey, $v d g=$ very dark grey, $g o=$ greyish olive, Mottles: $f=f e w, c=$ common, $m=$ many. $\mathrm{l}=$ fine, $2=$ medium, 3 = course, $d=$ distinct, $\mathrm{p}=$ prominent, $\mathrm{b}=$ brown, $\mathrm{yb}=$ yellowish brown. $\mathrm{dyb}=$ dark yellowish brown, $\mathrm{yr}=$ yellowish red. Structure: $1=$ weak, $2=$ moderate, $3=$ strong, $\mathrm{f}=$ fine, $\mathrm{m}=$ medium, $\mathrm{c}=$ course, $\mathrm{vc}=$ very course, $\mathrm{abk}=$ angular blocky, $\mathrm{pr}=$ prismatic Consistence: $\mathbf{w s}=$ wet sticky, $w p=$ wet plastic, $w s s=$ wet slightly sticky, $w p s=$ wet slightly plastic, $\mathrm{mvfi}=$ moist very firm, $\mathrm{mfi}=$ moist firm, $\mathrm{mfr}=$ moist friable. Boundary: as $=$ abrupi smooth, cs = clear smooth.

The cation exchange capacity of the soils ranged from 10.49 to $28.31 \mathrm{cmol} / \mathrm{kg}$ soil with a mean value of $20.10 \mathrm{cmol} / \mathrm{kg}$ soil. The amount of exchangeable $\mathrm{Ca}^{+}, \mathrm{Mg}^{+}, \mathrm{K}^{+}$and $\mathrm{Na}^{+}$ in the soils ranged from 6.30 to $12.21 \mathrm{cmol} / \mathrm{kg}$ soil, 2.28 to $4.87 \mathrm{cmol} / \mathrm{kg}$ soil, 0.32 to $0.92 \mathrm{cmol} / \mathrm{kg}$ soil, 1.09 to $2.84 \mathrm{cmol} / \mathrm{kg}$ soil, respectively. Figs. $9-13$ show an irregular trend in the vertical distribution of CEC, exchangeable $\mathrm{Ca}^{++}, \mathrm{Mg}^{++}, \mathrm{K}^{+}$and $\mathrm{Na}^{+}$in the profiles respectively. The base saturation percentage of the soils ranged from 53 to 98 with an average value of 78 . 
The environmental settings of the soils, their morphogenetic features and physicochemical properties clearly indicate that the parent materials of these soils are alluvial deposits of mixed origin. Profile characteristics of these soils showed that their development did not proceed too far. All the soils under investigation appear to be incompletely developed which means that they are still immature. This may be due to the short duration and the annual siltation that take place during flooding period. The soils may, therefore, be reasonably considered to be in its incipient stage of development. The parent materials and the conditions like the poor drainage and the aquic moisture regime due to regular submergence during the rainy season are probably the factors moulding the profile characteristics of the soils. The direct consequence of poor drainage is the retardation of leaching and negligible alteration of soil materials. Apart from that, the soils have been under cultivation for a long time which disturbed the normal pedological processes. A plough pan has also formed in the surface horizons of the soils. The finer fraction blocked the pore space and restricted to some extent the movement of the product of weathering. Seasonal wetting and drying set the condition of alternate reduction and oxidation in the soils. The reaction $(\mathrm{pH})$ of the soils closely follows the course of oxidation-reduction condition because the soils contain considerable amount

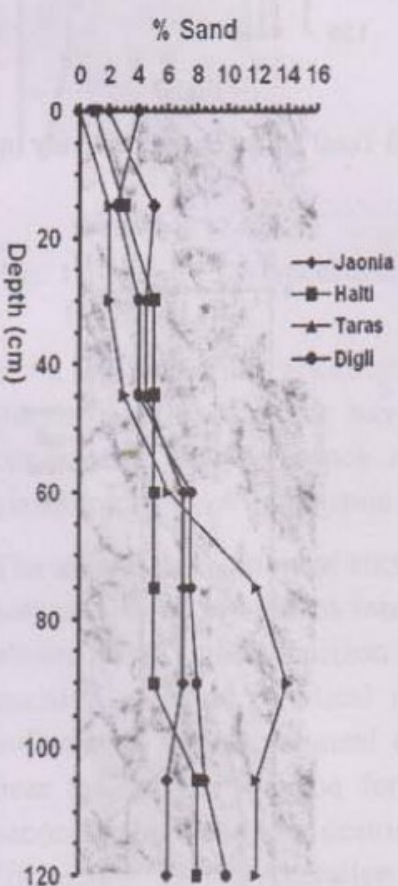

Fig. 2

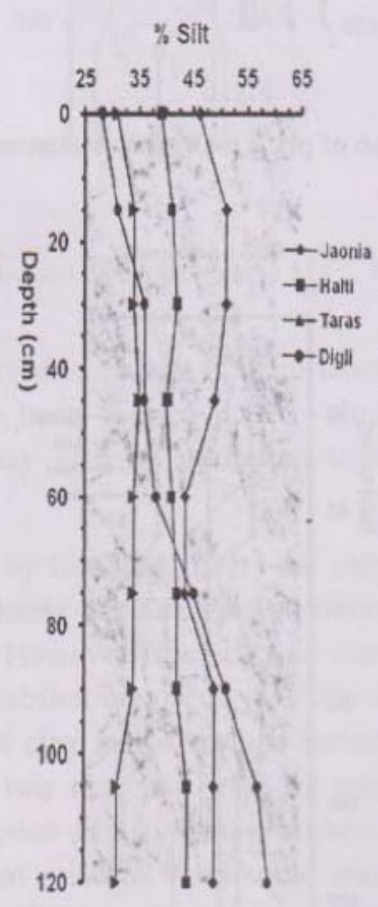

Fig. 3

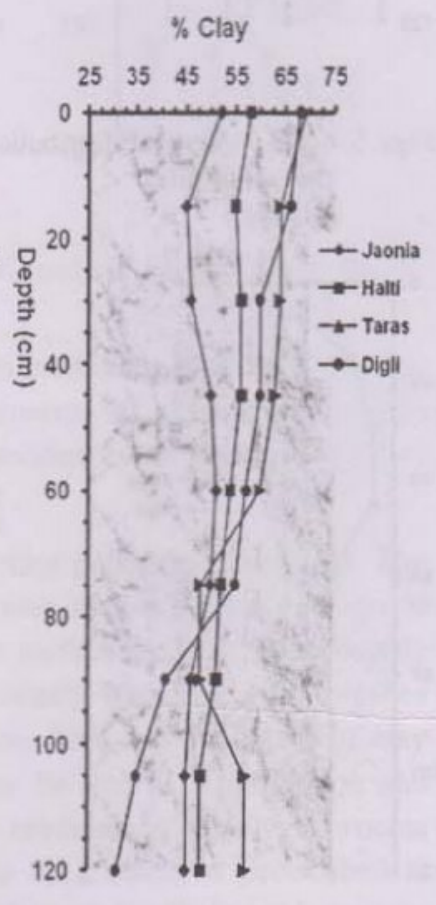

Fig. 4

Figs. 2, 3 and 4. Vertical distribution of sand, silt and clay, respectively in the soil profiles. 


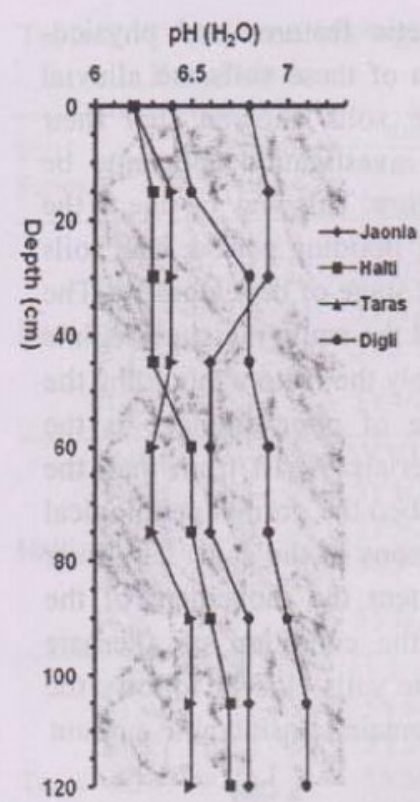

Fig. 5

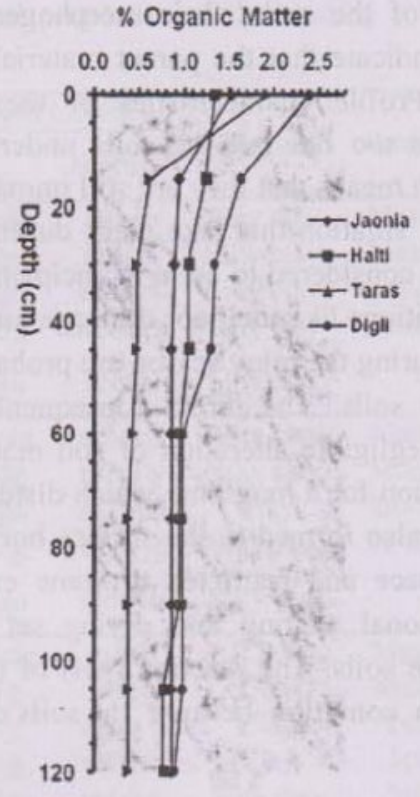

Fig. 6

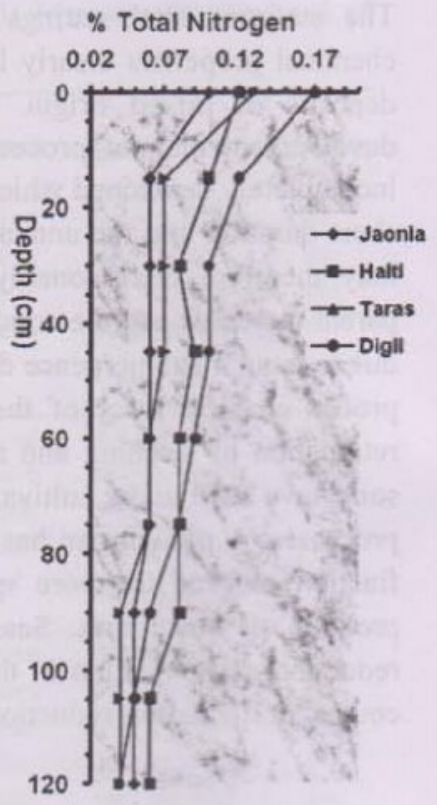

Fig. 7

Figs, 5, 6 and 7. Vertical distribution of $\mathrm{pH}_{\text {water, }}$ Organic Matter and Total Nitrogen, respectively in the soil profiles.

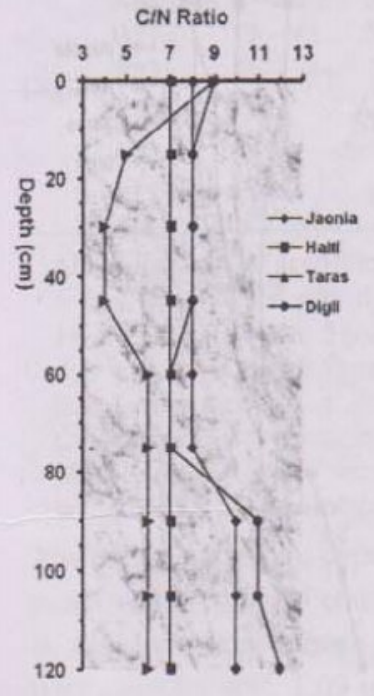

Fig. 8

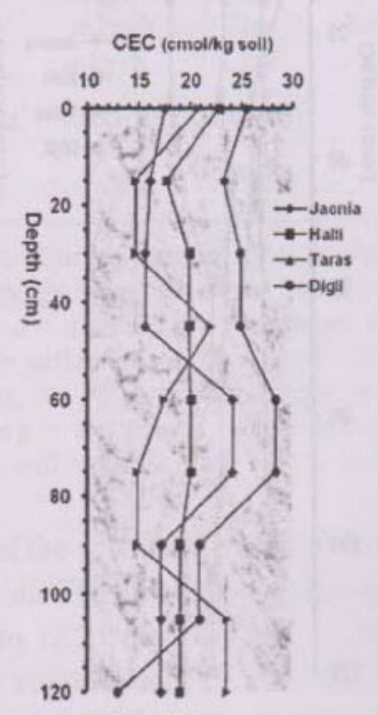

Fig. 9

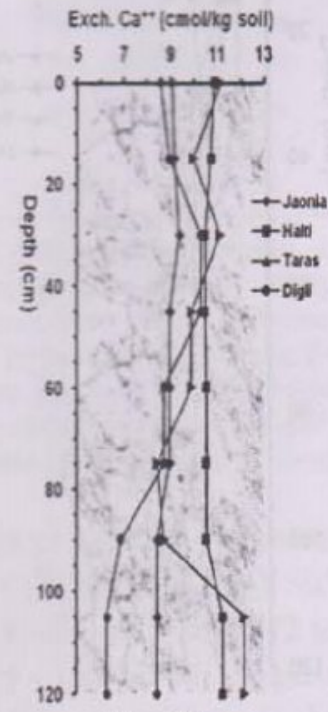

Fig. 10

Figs. 8, 9 and 10. Vertical distribution of $\mathrm{C} / \mathrm{N}$ ratio, $\mathrm{CEC}$ and exchangeable $\mathrm{Ca}^{++}$, respectively in the soil profiles. 
Exch. Mg** (cmol/kg soil)

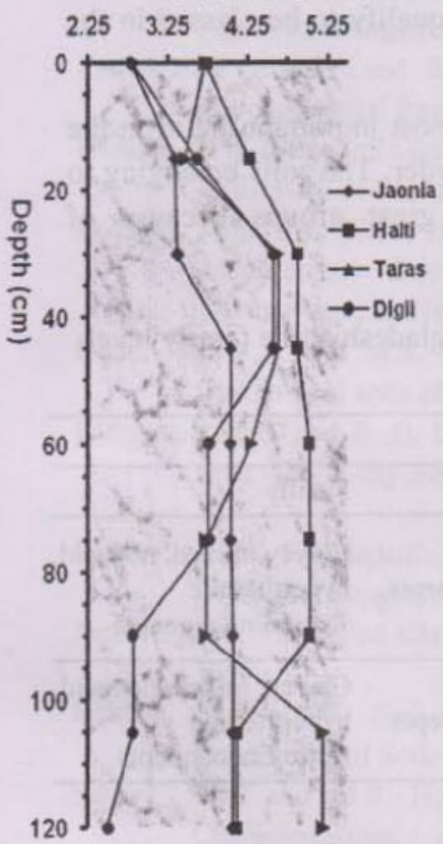

Fig. 11

Exch. $\mathrm{K}^{*}$ (cmol/kg soil)

$$
\begin{array}{llll}
0.25 & 0.45 & 0.65 & 0.85
\end{array}
$$

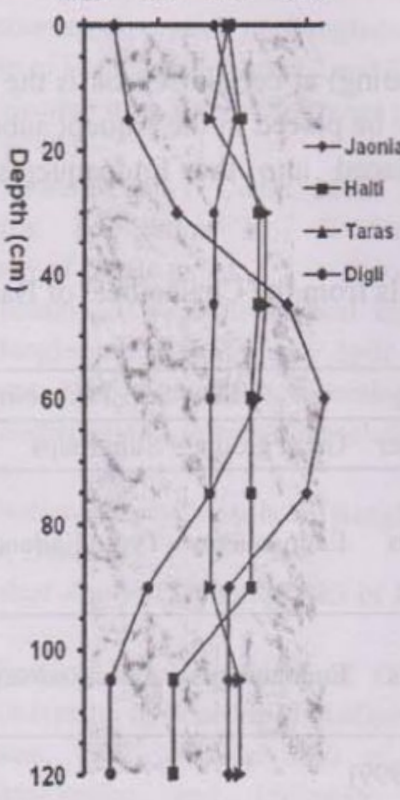

Fig. 12
Exch. $\mathrm{Na}^{+}$(cmol/kg soil)

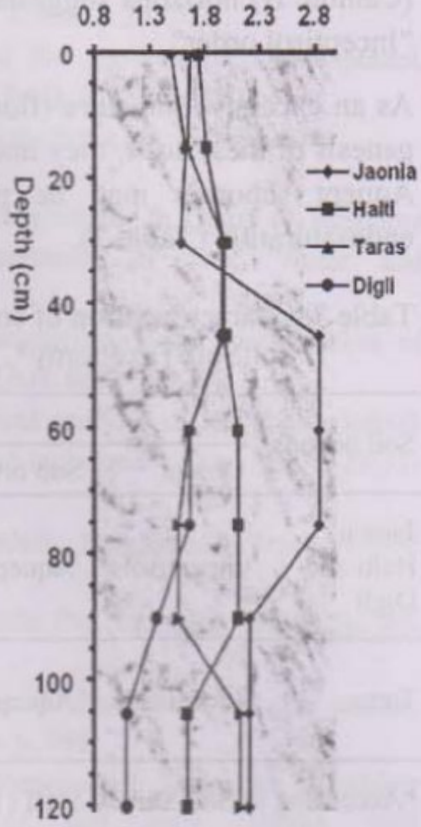

Fig. 13

Figs. 11,12 and 13. Vertical distribution of exchangeable $\mathrm{Mg}^{++}, \mathrm{K}^{+}$and $\mathrm{Na}^{+}$, respectively in the soil profiles.

of $\mathrm{Fe}$ and $\mathrm{Mn}$ which are subjected to change. The horizons containing mottles of various shapes, size and colour have been formed due to alternation of oxidation-reduction conditions. Their presence may also be attributed to evidences of a weak type of gleization process in the soils.

The annual deposition of silts by flooding affects the existing pedogenic processes. The soil profile with weak to moderate angular blocky structures suggests the formation of altered B (Cambic) horizon. However, the soils in the surface horizon have mostly massive structure. Vertical distribution of clay in the Jaonia and Halti soil profiles indicate an impoverishment of clay in the surface horizon. This lower content of clay near the surface may be for two reasons: firstly, it may be due to stratification and secondly there may be destruction of clay in the surface horizons by ferrolysis process (Brinkman 1970). Alteration of mica to vermiculite may be a common pedochemical weathering process in the soils of Chalan beel (Islam and Hussain 2008). But this process is not strong enough and as a result amount of vermiculite is small. Gleization, therefore, is thought to be the major process of soil formation in them. The structural B horizon in the subsoils of these profiles along with redox concentration and the regular decrease of 
organic matter may be designated as a cambic horizon. The presence of "structural B" (Cambic B) horizons suggests that all the studied soils may qualify to be classed in the "Inceptisol order".

As an excessive moisture (flooding) at certain season is the most important factor in the genesis of these soils, they may be placed in the Aquept suborder. The soils belonging to Aquept suborder may be placed into the Endoaquepts great groups because of endosaturation (Table 3).

Table 3. Characterization of soils from the Chalan beel of Bangladesh at the family level of Soil Taxonomy*.

\begin{tabular}{|c|c|c|c|c|c|}
\hline \multirow{2}{*}{ Soil pedons } & \multirow[b]{2}{*}{ Order } & \multicolumn{4}{|c|}{ USDA Soil Taxonomy } \\
\hline & & Sub order & Great group & Subgroups & Family \\
\hline $\begin{array}{l}\text { Jaonia, } \\
\text { Halti and } \\
\text { Digli }\end{array}$ & Inceptisols & Aquepts & Endoaquepts & Typic Endoaquepts & $\begin{array}{l}\text { Clayey, mixed, nonacid, } \\
\text { hyperthermic } \\
\text { Typic Endoaquepts }\end{array}$ \\
\hline Taras & Inceptisols & Aquepts & Endoaquepts & Aeric Endoaquepts & $\begin{array}{l}\text { Clayey, mixed, nonacid, } \\
\text { hyperthermic } \\
\text { Aeric Endoaquepts }\end{array}$ \\
\hline
\end{tabular}

*According to Soil Survey Staff (1999)

At the subgroup level Taras soils may be classed as Aeric Endoaquepts as it is relatively better drained and has mottles with chroma $\geq 2$ within $70 \mathrm{~cm}$ depth. The Jaonia, Halti and Digli soils fit in the Typic Endoaquepts subgroup because of colour chroma $\leq 2$ within 70 $\mathrm{cm}$ depth. On the basis of soil reaction, all the studied soils can be placed into the non acid class. Mineralogical studies indicated that the soils of Chalan beel had mixed mineralogy as they did not have any particular clay mineral which constituted more than $50 \%$ (Islam and Hussain 2008). In fact none of the clay minerals are dominant. It should be noted here that the soils under investigation have hyperthermic temperature regime and are medium to heavy textured. On the basis of textural class all the soils are classed as clayey. As indicated in the above discussion the soils have been placed into two soil families (Table 3). This family level classification may serve a useful vehicle for crop production and agro-technology transfer.

\section{References}

Brammer, H. 1996. The Geography of the Soils of Bangladesh. The University Press Limited. Dhaka. p. 287.

Brinkman, R. 1970. Ferrolysis: A hydromorphic soil forming process. Geoderma. 3: 199-206.

Day, P.R. 1965. Particle formation and particle size analysis. In: Methods of Soil Analysis (eds. C.A. Black et. al.) American Society of Agronomy, Madison, Wisconsin. pp. 545-567. 
FAO. 1977. Guidelines for soil profile description ( $2^{\text {nd }}$ edi.). Soil Resources Development and Conservation Service, Land and Water Development Division. Food and Agriculture Organization (FAO) of the United Nations, Rome. p.70.

FAO-UNDP. 1988. Land Resources Appraisal of Bangladesh for Agricultural Development. Agroecological Region of Bangladesh. Report 2 and 3. FAO, Rome. p. 570.

Hussain, M.S. 1992. Soil Classification with Special Reference to the Soils of Bangladesh. University of Dhaka. p. 433.

Hussain, M.S., S.F. Elahi, H. Eswaran, M. J. Uddin. 2003. Bangladesh: In Quest of Resource Management Domains. Publication No. 2. Department of Soil, Water and Environment, University of Dhaka. p. 83.

Islam, A.B.M.S. and M.S. Hussain. 2008. Mineralogical characterization of clay fraction of Chalan Beel soils of Bangladesh. J. Bangladesh Agril. Univ. 6(2): 253-260.

Islam, A.K.M.E. and E. G. Lotse, 1986. Quantitive Mineralogical analysis of some Bangladesh soils with X-ray ion exchange and selection dissolution techniques, Clay Miner. 21:3142.

Islam, S. 2003. Banglapedia, National Encyclopedia of Bangladesh. Banglapedia Trust. Asiatic Society of Bangladesh, Dhaka.

Jackson, M.L. 1967. Soil Chemical Analysis. Prentice Hall of India Pvt. Ltd. New Delhi. pp. 25. 145.

Jackson, M.L. 1975. Soil Chemical Analysis-Advanced Course. Published by the author. Department of Soils. University of Wisconsin, Madison. p. 991.

Saheed, S.M. and M.S. Hussain. 1992. Wetland Soils of Bangladesh. (ed. J.M. Kimble); Characterization, classification and utilization of wet soils. USDA Soil Conservation Service. National soil survey centre. Lincoln, NE. pp. 220-229.

Soil Survey Staff. 1993. Soil Survey Manual. USDA Handbook No.18. US Govt. Printing Office, Washington, D.C. p. 437.

Soil Survey Staff. 1999. Soil Taxonomy. A Basic System of Soil Classification for Making and Interpreting Soil Surveys ( $2^{\text {nd }}$ ed). Agric. Handb. No. 436, US Govt. Printing Office, Washington, D.C. p. 870.

SRDI Staff. 1965-86. Reconnaissance Soil Survey Report of Rajshahi District of Bangladesh. Govt. of Bangladesh. Farmgate, Dhaka. p. 150.

(Received revised manuscript on 01 June 2014) 